九州大学学術情報リポジトリ

Kyushu University Institutional Repository

\title{
A Study on the Development Project of Mountain Settlements in Korea
}

Kang, Hag Mo

Kyonggi-do Forest Environment Research Station

Choi, Soo Im

Korea Forest Research Institute

Kim, Jae Sung

Korea Forest Research Institute

Jeong, In Soo

Departmant of Forest Products, Iksan Nationial College

他

https://doi.org/10.5109/4644

出版情報：九州大学大学院農学研究院紀要. 50 (1)，pp. 295-311，2005-02-01. Faculty of Agriculture, Kyushu University

バージョン :

権利関係 : 


\title{
A Study on the Development Project of Mountain Settlements in Korea
}

\section{Hag Mo KANG ${ }^{*}$, Soo Im CHOI ${ }^{2}$, Jae Sung KIM², In Soo JEONG ${ }^{3}$, Seung Won $\mathrm{OH}^{4}$, Sang Hyun $\mathrm{LEE}^{4}$ and Noriko SATO}

\author{
Laboratory of Forest Policy, Division of Forest Environment and Management Sciences, \\ Department of Forest and Forest Products Sciences, Faculty of Agriculture, \\ Kyushu University, Fukuoka 812-8581, Japan \\ (Received November 5, 2004 and accepted November 11, 2004)
}

\begin{abstract}
The Korean government has finished the development of 69 villages by 2002 from the beginning of the first mountain village in 1995 and invested 119.2 billion won for the development cost of mountain settlements in order to cultivate a base village for forest management.

In 2003, basic research for the status of a mountain settlement was performed to use it as an effective way of promotion for the development policy of mountain settlements and establishment of a basic plan for 119 cities and guns, 508 counties and myeons, and 4,973 administrative units nationwide. However, the development projects of mountain settlements that have been promoted in former times present some problems, such as passive participation of the local residents and project promotion that does not reflect the characteristics of a local area. Therefore, this study establishes research that will contribute to the development project of a mountain settlement through an active investigation for the residents of 5 mountain villages in Gyeonggi Province, Korea.

From these results, the local residents decreased due to an increase in aging, lack of labor force, small-scale arable land, low grade of forest management, and not various incomes in spite of the improvement of a settlement base by introducing a forest development project. In order to process an effective development project of a mountain settlement, it can be seen that investment should be performed by considering the characteristics of the local area. In addition, the active participation of the local residents through a good enough discussion and a reflection of the residents' opinion are more important than anything else.
\end{abstract}

\section{INTRODUCTION}

Korea's mountain settlements cover $47 \%$ of the entire area but has $4 \%$ portion of population. In addition, it lies in poor conditions in social, cultural, and economic aspects due to its geological position. Especially, a low productivity and lack of labor force acts as a factor that will create some difficulties in economics. Moreover, the forest does not contribute to the increase in household income due to the lack of labor, wages increasing, and low grade of forestry production according to aging. However, mountain settlements play an important role in a stable agriculture and forestry production, balanced country development, and succession to the culture and tradition. On the other hand, although

\footnotetext{
1 Kyonggi-do Forest Environment Research Station, Osan, 447-290, Korea

2 Korea Forest Research Institute, Seoul, 130-712, Korea

3 Department of Forest Products, Iksan National Collage, Iksan, 520-752, Korea

+ Division of Forest Science, Chonbuk National University, Chonju, 561-756, Korea

* Corresponding author (E-mail: kanghagmo@hanmail.net)
} 
there are some activities for the supply of agricultural products and nature experiences through an interchange between the urban residents and the rural residents while the interest for an environmental problem increases throughout the world, there are some issues that still existed as an obstacle, which will interrupt the revitalization of mountain settlements due to the uncertain way in agriculture and forestry production, such as the absence of a successor, lack of labor, and changes in the domestic and foreign conditions. Therefore, the government had performed the development of mountain settlements for 69 villages in 2002 from the beginning of the development project of mountain settlements in 1995 to develop the underdeveloped mountain settlements. In addition, 240 villages will be developed by 2007 (Korea Forest Service, 2003b). However, there are few actual studies that have been done on the development project of a mountain settlement. Moreover, an analysis, which is focused on the reproduction and labor structure of farmers that makes it possible to grasp the existence of farmers, is required.

Therefore, the objective of this study gropes for the development project of mountain settlements and its way of promotion through an actual research for the residents of a mountain village in Gyeonggi province, Korea where the development project of mountain settlements has already finished.

\section{METHODS OF STUDY}

The investigation was performed for the area where the development project of mountain settlements has already finished from 1996 to 2002 for 46 householders of residents who lived in 5 mountain villages, such as Suksan-Li Danwol-Myeon, Yangpyeong County (10 persons), Kwangam-Dong Syaemok village, Dongducheon City (8 persons), Sanjoon-Li Keumkwang-Myeon, Ansung City (7 persons), Hapum-Li Sanbuk-Myeon, Yeojoo County (11 persons), and Baekdun-Li Buk-Myeon, Gapyeong County (10 persons).

The investigation questionnaire was done by using a personal interview with the residents from early July to early August, 2004 for 1 month and dealt with the reproduction structure of the state of employment, configuration of income, state of managed arable land, situation of cropping, and situation of forest management, the situations of facilities management and business operation that were produced by the results of general opinion and development project of mountain settlements for the reproduction structure and labor organization, and the development direction of mountain settlements in the future. The materials acquired from the investigation were analyzed according to the area, sex of the labor force, and scale of the managed arable land.

On the other hand, the changes in the trend of internal migration for the 5 villages presented 165 people from 43 households before the project in Suksan-Li Danwol-Myeon, Yangpyeong County where the development project was already finished from 1996 to 1998 but decreased in inhabitants by 23 people from 165 people to 142 people from 43 households after the project. However, there were 4 people from 3 households who moved in from an external territory. In the case of Kwangam-Dong Syaemok village, Dongducheon City where the development project was already finished from 1998 to 2000 , there were 130 local residents before the project but increased in inhabitants for the local residents of 147 people and remove of 17 people respectively after the project. 
For Sanjoon-Li Keumkwang-Myeon, Ansung City where the development project was already finished from 1999 to 2001, presented 221 people from 66 households before the project but decreased by 173 people from 63 households after the project. However, the removers increased by 15 people from 5 households. In the case of Hapum-Li Sanbuk-Myeon, Yeojoo County where the development project was already finished from 1999 to 2001, there was 205 local residents before the project but decreased by 194 after the project. However, the removers increased by 12 people. Finally, Baekdun-Li Buk-Myeon, Gapyeong County where the development project was already finished from 2000 to 2002 presented 328 people from 124 households of the local residents before the project but decreased by 45 people from 328 people to 283 people. From the investigation for the changes of the inhabitants of 5 villages, the 4 villages decreased in the local residents by 110 people and increased in the removers of 48 people except for the village of Kwangam-Dong Syaemok village, Dongducheon City (Gyeonggi province, 2003a).

However, the purposes of the movers were largely covered in a house lodging or restaurant using the surrounding natural environment rather than engaging in the agriculture and forestry industry. In addition, there were some people who enjoyed rural life and weekend farming.

\section{RESULTS AND DISCUSSION}

\section{The present situation of the development project of mountain settlements in Korea}

The government defines mountain settlements, which is located in a remote and secluded place in the mountains, that shows a high occupation rate of forest land, low income, weakness in the base of industry due to the estrangement from the social, economical, and cultural benefits, and depopulation area with a low level of environmental arrangement. For further details on the definition, a forest rate of over $70 \%$, an arable land rate under $26 \%$, population density of $1.44 / \mathrm{km}^{2}$ were used as an index to classify mountain settlement at that time of the investigation. However, the index was changed by following the enactment of the basic laws of forest in 2001 that defined the forest rate of over $70 \%$ for the administrative area of Yup and Myeon, population density under the average of Yup and Myeon throughout the country, and arable land for the administrative area under the average of Yup and Myeon throughout the country.

The area of mountain settlements covers $47 \%\left(46,181 \mathrm{~km}^{2}\right)$, the forest area is $58 \%$ ( 3.746 million ha), arable land is $27 \%$ (548,000 ha) of the entire area but has only a $4.6 \%$ (1.94 million) portion of population. Therefore, the development project (A modernization project for an agricultural, mountain, and sea village) of mountain settlements for one model village in 1995 has started to make a balanced national land development, manage and use forest effectively, and increase the income of the inhabitants lived in an underdeveloped mountain settlement.

However, the development project of a mountain settlement has some problems due to the lack of juridical basis in its promotion but can be systematically and stably promoted by introducing the more detailed regulations for the promotion of mountain settlements based on the basic laws of forest (Proclamation: May 23, 2001) and law of the promotion of forestry industry and mountain settlements (Revision and Proclamation: 
Dec 31,2001 ). In 2002 , the laws related to mountain settlements were totally rearranged by the revision of the enforcement laws and regulations by following the revision of the law of the promotion of forestry industry and mountain settlements. In 2003, a basic research for the status of mountain settlements was performed to use it as an effective way of promotion for the development policy of mountain settlements and establishment of a basic plan for 119 cities and counties, 508 Eups and Myeons, and 4,973 administrative units nationwide based on the law of the promotion of the forestry industry and mountain settlements (Revision and Proclamation: Dec 31, 2001).

On the other hand, the development projects of mountain settlements were performed for 3 villages in 1996, and 5 villages in 1997. In addition, a model project was also performed for all provinces in which the project was applied to 9 villages and 1 village per province until 1997. The projects were started on a full scale in 1998 and performed as of now in 2002 for 69 villages with a cost of 119.2 billion won. In addition, 10 villages are still in the design process, and 240 villages will be finished until 2007. The projects were processed by four types, such as a recreation related type, forestry profits type, agricultural complex type, and integrated development type mountain settlements by considering the area characteristics in which the cost of the development project of mountain settlements was invested with the three large sections, such as the creation of a production base (forestry production base facilities, mountain settlements industry base, etc.), improvement of settlement environments (village base creation project, culture and welfare facilities, environmental purification facilities, etc.), and development of a profit source (individual profits business using a forest and recreation facility, etc.).

However, there are some different studies on the results of this project from the viewpoint of the needs of various methods to increase the promotion capitals of mountain settlements, passive participation of the residents, and necessity of the project promotion fitted for the characteristics of mountain settlement besides the indications of the government, such as the strengthening of the post-counter plan to operate a base facility for

Table 1. Results of investment and plans of the forest village development.

(Unit: hundred won)

\begin{tabular}{|c|c|c|c|c|c|c|}
\hline Classification & $\begin{array}{c}\text { Amount of } \\
\text { objects } \\
(1995 \sim \\
2007 \mathrm{yr})\end{array}$ & $\begin{array}{l}1995 \sim \\
2000 \mathrm{yr}\end{array}$ & $2001 y r$ & $2002 y r$ & $\begin{array}{c}2003 y r \\
\text { plan }\end{array}$ & $\begin{array}{l}2004 \sim \\
2007 \mathrm{yr}\end{array}$ \\
\hline $\begin{array}{l}\text { An advance design } \\
\text { (a place) }\end{array}$ & 240 & 76 & 17 & 15 & 10 & 122 \\
\hline Finished village & 240 & $25(38)$ & $22(47)$ & $22(59)$ & $15(49)$ & 116 \\
\hline Cost of investment & 472,839 & 71,171 & 23,457 & 24,561 & 28,960 & 324,690 \\
\hline -Government subsidy & 294,084 & 40,370 & 13,387 & 16,387 & 18,827 & 205,113 \\
\hline -Local funding & 34,890 & 16,881 & 4,790 & 1,634 & 2,333 & 9,252 \\
\hline -Local expenditure & 143,865 & 13,920 & 5,280 & 6,540 & 7,800 & 110,325 \\
\hline
\end{tabular}

Note: Numerical values of inside in the parentheses are numbers of the business.

Source: 1) Forestry service. 2003a An annual report about forest and forestry: 283-306.

2) Forest service. 2003b A guidebook for basic census of forest settlements: 1-59. 
income and the activation of mortgage project (Gyeonggi provice, 2003c, 2004; Korea Forest Service, 2003a; Kwak and Kim, 2002) (Table 1).

\section{The present status of the development project of mountain settlements in Gyeonggi Province}

The development project of mountain settlements in Gyunggi Province was started from Suksan-Li Danwol-Myeon, Yangpyeong-Gun in 1996 and finished for 7 villages as of now in 2003. It will be finished for 4 villages until 2003 2004. In addition, it has been planned for 1 village in 2005 (Shon and Chang, 2002; Kim, 2002).

From the results of the investment from 1996 to 2003 and by 2003 to 2004 , about 18.7 billion won for 10 villages has been invested in which the average cost per village was 1.9 billion won. The cost consists of a supplementary project and financing project. First of all, a supplementary project consists of an improvement project of life-environment to change the settlement environments, such as a village hall, pavement of village road, arbor, sewage purification system, and other things and a creation project of a production base to increase the income of the residents, such as a local specialty shop, cultivation house of Oak mushroom, cold storage, forage profits complex, forage grazing, and other

Table 2. The results of the development for mountain setllements in Gyeonggi province.

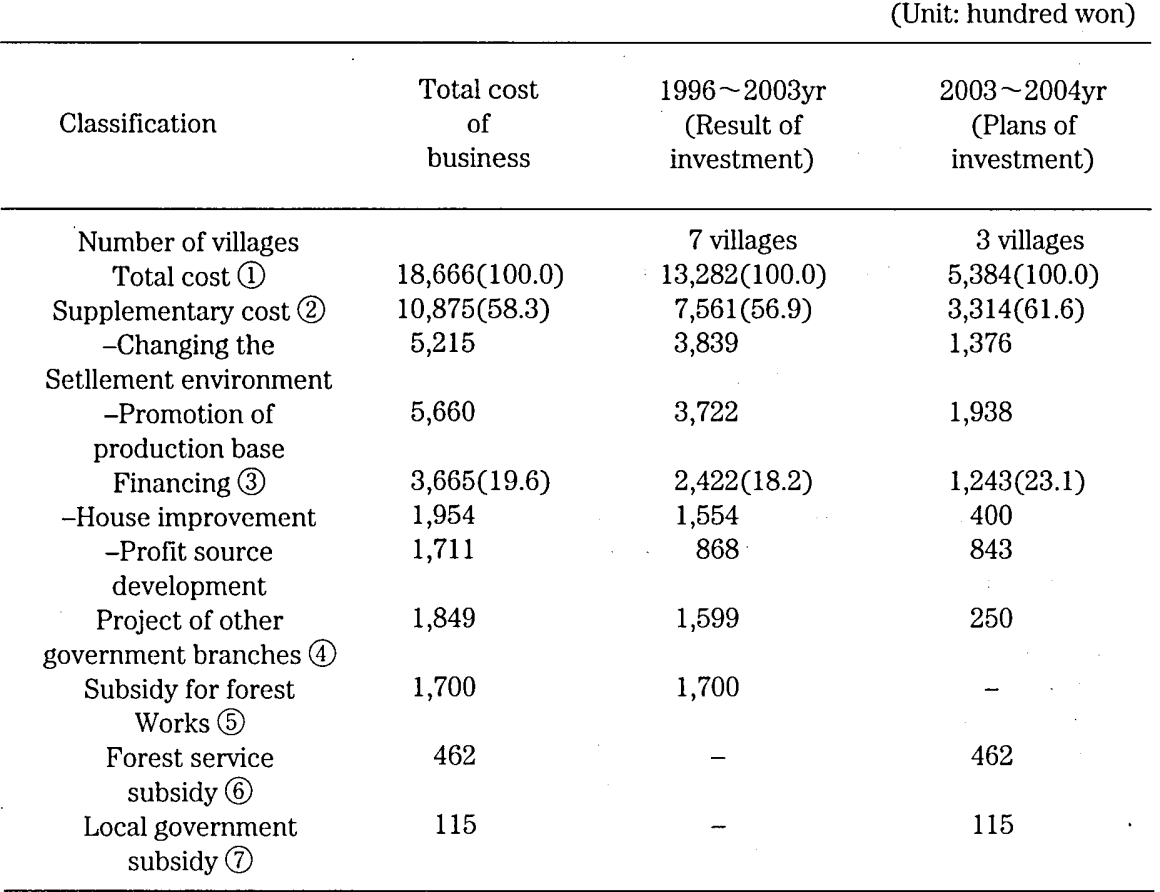

Note: 1) Numerical values of inside in the parentheses are percent of composition (\%)

2) $(1)=(2)+(3)+(4)+(5)+(6)+(7)$

Source: Gyeonggi province. 2003. The situations of the development for mountain settlements 
various things. The cost of a mortgage project covered about $20 \%$ of the total cost but mainly consisted of a profit source development project that was directly related to the increase of income of the residents, such as the construction of a new house or enlargement of a building, cultivation of wild edible greens, fruit orchard complex, and cultivation of Oak mushrooms. Besides, a number of different branches related projects and supports of the Korea Forest Service were supplied to some of the mountain settlements. However, there are some indications that the characteristics of individual village will be fully considered in the case of the creation project of a production base. In addition, the results of the mortgage project was very small due to a lack of well greeting from the residents for the interest and refinement period (Gyeonggi province, 2003b) (Table 2).

\section{Case studies on the development project of mountain settlements in Gyeonggi Province}

Reproduction structure

a) Configuration of labor force

The age of household members over 20 was 110 people for 46 households in which the average household members were 2.4 people. The average household member and age were 2.3 people and 50 in the case of Yeojoo City, 2.0 people and 60 for Gapyeong County, 2.6 people and 51 for Dongducheon City, and 2.3 people and 59 for Ansugn City. The age of people in their 50 s was $32.7 \%$ as the largest distribution, 60 s was $20.9 \%$, and 40 s was $20.0 \%$ in its age composition. However, the age of $40 \mathrm{~s}$ and $50 \mathrm{~s}$ were $23.8 \%$ and $42.9 \%$ (total $66.7 \%$ ) respectively in Dongducheon city, $34.8 \%$ and $21.7 \%$ (total $56.5 \%$ ) for Gapyeong County, $20.0 \%$ and $33.3 \%$ (total 53.3\%) for Yeojoo City. On the other hand, the age of people their over $60 \mathrm{~s}$ and 70 s were $40.0 \%$ and $56.3 \%$ in the case of Yangpyeong

Table 3. Configuration of labor force in household.

\begin{tabular}{|c|c|c|c|c|c|c|c|c|c|}
\hline & & & & & & & & Unit: pe & erson) \\
\hline \multirow{2}{*}{ Classification } & \multicolumn{3}{|c|}{ Total } & \multirow{2}{*}{20 's } & \multirow{2}{*}{30 's } & \multirow{2}{*}{40 's } & \multirow{2}{*}{50 's } & \multirow{2}{*}{60 's } & \multirow{2}{*}{$\begin{array}{l}\text { Over } \\
70 \text { 's }\end{array}$} \\
\hline & Total & male & female & & & & & & \\
\hline Total & \multirow[t]{2}{*}{110} & 57 & 53 & 6 & 10 & 22 & 36 & 23 & 13 \\
\hline (46 households) & & $(51.8)$ & $(48.2)$ & $(5.5)$ & $(9.1)$ & $(20.0)$ & $(32.7)$ & $(20.9)$ & (11.8) \\
\hline Yeojoo country & \multirow[t]{2}{*}{30} & 15 & 15 & 3 & 4 & 6 & 10 & 5 & 2 \\
\hline (11 households) & & $(50.0)$ & $(50.0)$ & $(10.0)$ & (13.3) & $(20.0)$ & $(33.3)$ & $(16.7)$ & $(6.7)$ \\
\hline \multirow{2}{*}{$\begin{array}{l}\text { Gapyeong country } \\
\text { (10 households) }\end{array}$} & \multirow[t]{2}{*}{23} & 11 & 12 & - & 2 & 8 & 5 & 2 & 6 \\
\hline & & $(47.8)$ & $(52.2)$ & - & $(8.7)$ & $(34.8)$ & $(21.7)$ & $(8.7)$ & $(26.1)$ \\
\hline \multirow{3}{*}{$\begin{array}{c}\text { Yangpyeong } \\
\text { country } \\
\text { (10 households) }\end{array}$} & \multirow[t]{3}{*}{20} & 10 & 10 & 1 & 1 & 3 & 8 & 7 & 1 \\
\hline & & $(50.0)$ & $(50.0)$ & $(4.8)$ & $(5.0)$ & $(15.0)$ & $(40.0)$ & $(35.0)$ & $(5.0)$ \\
\hline & & & & & & & & & \\
\hline \multirow{2}{*}{$\begin{array}{l}\text { Dongduchon city } \\
\text { ( } 8 \text { households) }\end{array}$} & \multirow[t]{2}{*}{21} & 13 & 8 & 2 & 2 & 5 & 9 & 2 & 2 \\
\hline & & $(61.9)$ & $(38.1)$ & $(12.5)$ & (9.5) & $(23.8)$ & $(42.9)$ & $(9.5)$ & (9.5) \\
\hline Ansung city & 16 & 8 & 8 & & 1 & & 4 & 7 & 2 \\
\hline (7 house holde) & & $(50.0)$ & $(50.0)$ & & $(6.3)$ & & $(25.0)$ & $(43.8)$ & (12.5) \\
\hline
\end{tabular}

Note: 1) Numerical values of inside in the parentheses are percent of composition (\%).

2) Households members under 20 years old are excluded on total.

Source: The data was colleted from early july to early august, 2004 for 1 month by personal interview. 
County and Ansung City, respectively that presented a higher rate of an aged person compared with the three villages mentioned above (Table 3).

b) The present status of managed arable land

The 11 households that cover $24 \%$ of the total cases of 46 households have no managed arable land. On the other hand, the arable land possessed by the rest of 35 households was 27.9 ha. The arable acreage of 27.9 ha consists of 9.4 ha of a rice field (33.7\%), 11.8 ha of an ordinary field, and 6.7 ha of orchards in which an ordinary field shows the highest portion of the land. However, the rate of a rice field and ordinary field was nearly the same in Yeojoo City. Gapyeong County presented $79 \%$ of the rate of orchards, Yangpyeong County presented $50 \%$ of a rice and ordinary field, respectively. Dongducheon City presented 100\% of an ordinary field, and Ansung City presented 68\% of a rice field.

In addition, the average managed arable land was 0.6 ha for 5 villages investigated in this study in which the average arable acreage per household was 0.3 ha for Yeojoo City, 0.8 ha for Gapyeong County, 0.7 ha for Yanpyeong County, 0.5 ha for Dongducheon City, and 0.7 ha for Ansung City (Table 4).

Table 4. The statues of managed arable land by size.

\begin{tabular}{|c|c|c|c|c|c|c|}
\hline Classification & Total & NAL* & $\begin{array}{c}\text { Under } \\
0.5 \mathrm{ha}\end{array}$ & $0.5 \sim 1.5 \mathrm{ha}$ & $1.0 \sim 1.5 \mathrm{ha}$ & $\begin{array}{l}\text { Over } \\
1.5 \mathrm{ha}\end{array}$ \\
\hline Total & $\begin{array}{l}27.9 \\
(46)\end{array}$ & (11) & $\begin{array}{l}1.4 \\
(8)\end{array}$ & $\begin{array}{l}11.2 \\
(16)\end{array}$ & $\begin{array}{l}9.6 \\
(8)\end{array}$ & $\begin{array}{l}5.7 \\
(3)\end{array}$ \\
\hline Yeojoo & 3.6 & & 0.4 & 2.2 & 1.0 & - \\
\hline (46households) & (11) & (4) & (3) & (3) & (1) & \\
\hline Gapyeong & 8.2 & & 0.1 & 2.7 & 3.3 & 2.1 \\
\hline (11households) & (10) & (1) & (1) & (4) & (3) & (1) \\
\hline Yangpyeng & 7.3 & & 0.6 & 2.4 & 2.7 & 1.6 \\
\hline (10households) & (10) & (1) & (3) & (3) & (2) & (1) \\
\hline Dongduchon & 4.1 & & - & 2.8 & 1.3 & \\
\hline (8households) & (8) & (3) & & (4) & (1) & - \\
\hline Ansung & 4.7 & & 0.3 & 1.1 & 1.3 & 2.0 \\
\hline (7households) & (7) & (2) & (1) & (2) & (1) & (1) \\
\hline
\end{tabular}

Note: Numerical values of inside in the parentheses are percent of composition (\%).

$*=$ No managed arable land

Source: The data was colleted from early July to early august, 2004 for 1 month by personal interview.

c) The present status of cropping

The 35 households that they possessed arable land among 46 households cultivated rice in the case of a rice field and vegetables like corn, bean, red pepper in the case of an ordinary field. In addition, most of fruits in orchards were apple (Table 5).

d) The present status of land transference

For the present status of the purchase and disposal of a rice and ordinary field, and forestland, there were no deals in Dongducheon and Ansung Cities. However, 3.2 ha for 
Table 5. The status of cropping by ownership.

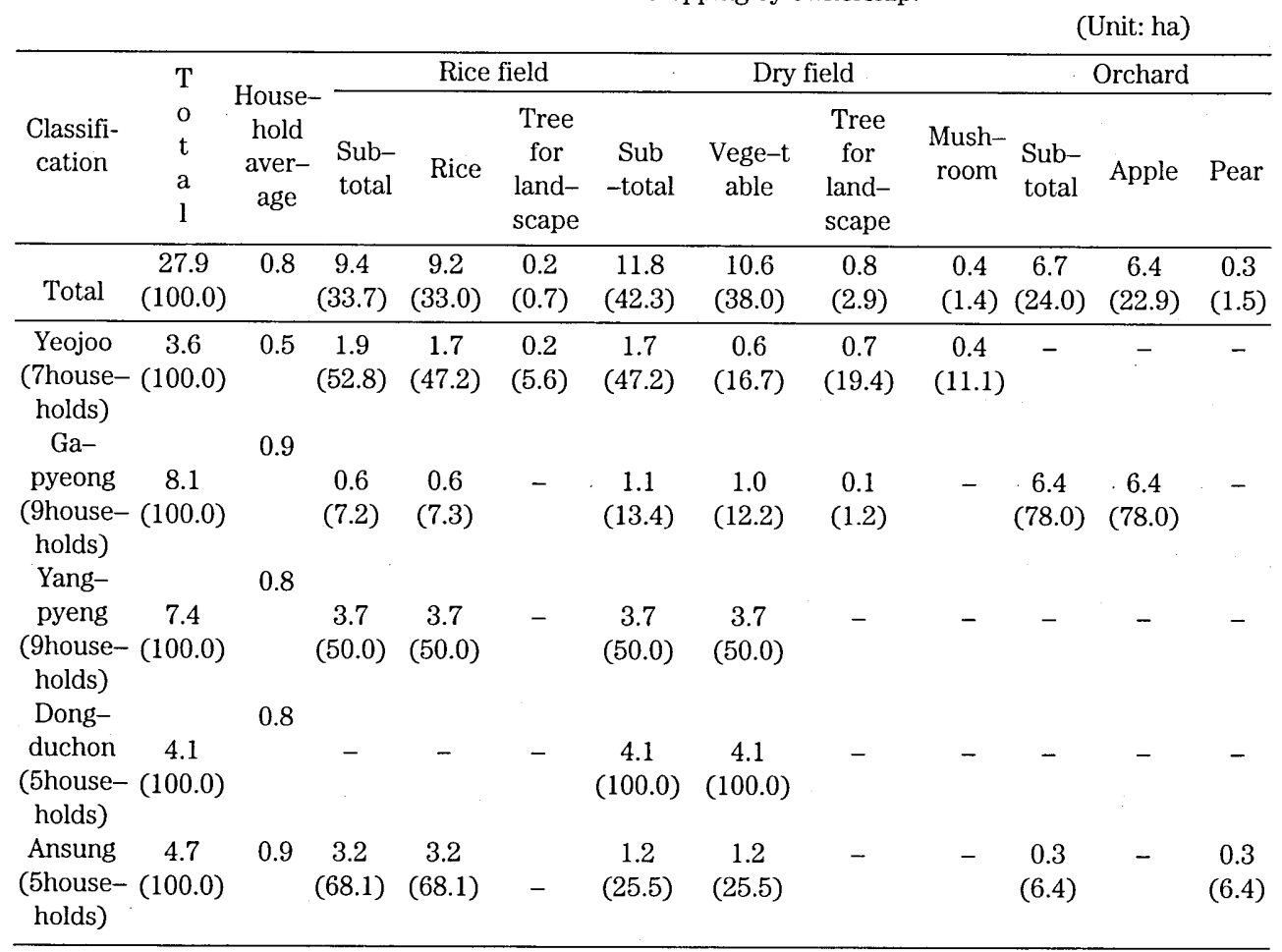

Note: Numerical values of inside in the parentheses are percent of composition (\%).

Source: The data was colleted from early july to early august, 2004 for 1month by personal interview.

the purchase of a rice and ordinary field, and orchards were dealt in 3 villages of Yeojoo City, Gapyeong County, and Yangpyeong County from 1970s to 2000s but 6.6 ha was sold as much as twice of the purchase. The purchase was relatively large in the 1970s and the 1990 s, but the sale was large in the 1980s and the 1990s.

On the other hand, the purchase of forestland was 8.4 ha, but the sale that was 12.6 ha presented higher than that of the purchase. The purchase of forestland was largely dealt in the 1980s and the 1990s. However, the sale was the largest in the 1980s with the amount of 7.3 ha but was 1.3 ha and 1.7 ha in the $1990 \mathrm{~s}$ and the $2000 \mathrm{~s}$, respectively. Therefore, the managed scale of arable land and forest land continuously decreased in order to cover the cost of education and marriage, house construction, and so on. On the other hand, the purchase was largely done for the enlargement of managed arable land (Table 6).

e) The present status of household income

The average gross income for 45 households of 5 villages in 2003 was 1.55 billion won and was significantly lowered to the average income of 2.69 billion won for the whole agricultural household throughout the country and of 2.53 billion won for a urban household. 
Table 6. The status of land owners transference by ownership.

(Unit: ha)

\begin{tabular}{|c|c|c|c|c|c|c|c|c|c|c|}
\hline \multirow{2}{*}{\multicolumn{2}{|c|}{ Classification }} & \multicolumn{5}{|c|}{ Purchase } & \multicolumn{4}{|c|}{ Disposal } \\
\hline & & Total & $\begin{array}{l}\text { Rice- } \\
\text { field }\end{array}$ & $\begin{array}{l}\text { Dry } \\
\text { field }\end{array}$ & Orchard & $\begin{array}{c}\text { Forest } \\
\text { land }\end{array}$ & Total & $\begin{array}{l}\text { Rice } \\
\text { field }\end{array}$ & $\begin{array}{l}\text { Dry } \\
\text { field }\end{array}$ & $\begin{array}{c}\text { Forest } \\
\text { land }\end{array}$ \\
\hline \multirow{6}{*}{$\begin{array}{l}\mathrm{Y} \\
\mathrm{e} \\
\mathrm{a} \\
\mathrm{r}\end{array}$} & Total & 27.2 & 16.3 & 8.8 & 2.1 & 61.3 & 6.6 & 3.4 & 3.2 & 12.6 \\
\hline & Inheri-tance & 24.0 & 14.2 & 8.0 & 1.8 & 52.9 & - & - & - & - \\
\hline & 1970’s & 1.2 & 0.9 & - & 0.3 & - & - & - & - & 2.3 \\
\hline & 1980's & 0.7 & 0.7 & - & - & 6.7 & 4.5 & 1.6 & 2.9 & 7.3 \\
\hline & 1990's & 1.2 & 0.5 & 0.7 & - & 1.7 & 1.8 & 1.5 & 0.3 & 1.3 \\
\hline & 2000 's & 0.1 & - & 0.1 & - & - & 0.3 & 0.3 & - & 1.7 \\
\hline \multirow{5}{*}{$\begin{array}{l}\mathrm{R} \\
\mathrm{e} \\
\mathrm{g} \\
\mathrm{i} \\
\mathrm{o} \\
\mathrm{n}\end{array}$} & Yeojoo & 4.1 & 2.4 & 1.7 & - & 16.1 & 4.7 & 1.9 & 2.8 & 9.0 \\
\hline & Ga-pyeong & 8.0 & 1.0 & 5.2 & 1.8 & 34.0 & 0.7 & 0.6 & 0.1 & 3.6 \\
\hline & Yang-pyeng & 3.5 & 3.5 & - & - & 9.9 & 1.2 & 1.0 & 0.2 & - \\
\hline & Dong-duchon & 3.9 & 3.9 & -1.9 & - & - & - & - & - & - \\
\hline & Ansung & 7.7 & 5.5 & & 0.3 & 1.3 & - & - & - & - \\
\hline
\end{tabular}

Note: Forestlands are excluded in the total.

Source: The data was colleted from early july to early august, 2004 for 1 month by personal interview.

From the gross income of the whole of 45 households, it showed in order of $34 \%$ for a small-scale business, $29 \%$ for agriculture, usual salaried labor for $17 \%$, and temporary salaried labor for $10 \%$. In the case of large managed arable land, it showed a higher rate of gross income. On the other hand, the gross income presented a high rate in order of the age of $30 \mathrm{~s}, 40 \mathrm{~s}$, and $50 \mathrm{~s}$ for all villages but in order of $41 \%$ for the age of $40 \mathrm{~s}, 27 \%$ for the age of $60 \mathrm{~s}, 26 \%$ for the age of $50 \mathrm{~s}, 33 \%$ for the age over 70 , and $8 \%$ for the age of $30 \mathrm{~s}$ in the case of the portion of agriculture for the total income.

The gross income for each area presented in order of 9.4 million won for Yangpyeong County, 10.7 million won for Ansung City, 15.8 million won for Yeojoo City, 18.3 million won for Dongducheon City, and 22.3 million won for Gapyeong County in which the usual salaried labor and small scale business covered by $37 \%$ and $23 \%$, respectively in Yangpyeong County and the small scale business and temporary salaried labor covered by $63 \%$ and $30 \%$, respectively in Dongducheon City. However, the agriculture and small scale business presented by $59 \%$ and $34 \%$ respectively in Gapyeong County, and agriculture and small scale business presented by $40 \%$ and $34 \%$ in Ansung City in which the rate of agriculture was a little higher than other areas (Table 7).

f) Plan for agriculture and forest management

The research for the future household life presented in order of 15 households of agriculture and orchards, 10 households of small scale business, 7 households of usual salaried labor, and 6 households of mushroom and garden trees cultivation. In the case of the scale of managed arable land, the household that they does not manage or under 0.5 ha were 19 households in which only 1 household managed the land for agriculture and 9 households managed in a small scale business and usual salaried labor among them. The households that they managed in agriculture and orchards, mushroom and garden trees cultivation as an economical base of life were 15 and 6 households respectively 
Table 7. The status of household income.

(Unit: hundred won)

\begin{tabular}{|c|c|c|c|c|c|c|c|c|c|c|}
\hline & lassification & Total & $\begin{array}{l}\text { Average } \\
\text { income }\end{array}$ & $\begin{array}{c}\text { Selfbusi } \\
\text {-ness }\end{array}$ & $\begin{array}{c}\text { Agricul } \\
\text {-ture }\end{array}$ & $\begin{array}{l}\text { Usual } \\
\text { salaried } \\
\text { labor }\end{array}$ & $\begin{array}{c}\text { Temp-o } \\
\text { rary } \\
\text { salaried } \\
\text { labo }\end{array}$ & $\begin{array}{l}\text { Mush } \\
\text {-room }\end{array}$ & Interest & $\begin{array}{l}\text { Stock } \\
\text { raising }\end{array}$ \\
\hline \multirow{8}{*}{$\begin{array}{l}\stackrel{\circledast}{\mathrm{M}} \\
\mathrm{A} \\
\mathrm{L}\end{array}$} & Total & $\begin{array}{r}712.2 \\
(100.0)\end{array}$ & 15.5 & $(34.2)$ & (29.3) & (17.4) & $(10.1)$ & $(5.2)$ & $(3.5)$ & $(0.4)$ \\
\hline & No land & $\begin{array}{r}100.2 \\
(100.0)\end{array}$ & 9.1 & (29.9) & - & $(27.5)$ & (38.5) & $(3.0)$ & $(0.1)$ & - \\
\hline & Under & 141.5 & 17.7 & $(28.8)$ & (11.1) & $(32.5)$ & (2.1) & (8.5) & $(17.0)$ & - \\
\hline & $0.5 \mathrm{ha}$ & $(100.0)$ & & & & & & & & \\
\hline & $\begin{array}{l}0.5 \sim \\
0.1 \text { ha }\end{array}$ & $\begin{array}{r}241.5 \\
(100.0)\end{array}$ & 15.1 & (48.5) & (29.3) & $(6.2)$ & $(10.8)$ & (4.1) & - & $(1.0)$ \\
\hline & $1.0 \sim$ & 149.6 & 18.7 & (32.1) & $(34.8)$ & (23.4) & $(2.6)$ & $(7.2)$ & - & - \\
\hline & $1.5 \mathrm{ha}$ & $(100.0)$ & & & & & & & & \\
\hline & $\begin{array}{l}\text { Over } \\
1.5 \mathrm{ha}\end{array}$ & $\begin{array}{r}79.5 \\
(100.0)\end{array}$ & 26.5 & $(10.1)$ & (88.7) & - & - & (1.3) & - & - \\
\hline \multirow{5}{*}{$\begin{array}{l}\text { A } \\
\mathrm{g} \\
\mathrm{e}\end{array}$} & 30 's & $\begin{array}{r}74.6 \\
(100.0)\end{array}$ & 24.9 & $(59.0)$ & $(7.5)$ & $(32.2)$ & (1.3) & - & - & - \\
\hline & 40 's & $\begin{array}{r}244.2 \\
(100.0)\end{array}$ & 24.4 & (41.4) & (41.3) & - & (13.2) & (4.1) & - & - \\
\hline & 50 's & $\begin{array}{r}311.1 \\
(100.0)\end{array}$ & 16.4 & $(28.6)$ & $(25.7)$ & $(24.0)$ & $(6.6)$ & (7.4) & $(7.7)$ & - \\
\hline & 60's & $\begin{array}{r}73.3 \\
(100.0)\end{array}$ & 7.3 & $(6.5)$ & $(26.6)$ & $(34.1)$ & $(24.3)$ & (5.0) & - & $(3.4)$ \\
\hline & Over 70's & $\begin{array}{r}9.0 \\
(100.0)\end{array}$ & 2.3 & (55.6) & (33.3) & - & - & - & (11.1) & - \\
\hline \multirow{5}{*}{$\begin{array}{l}\mathrm{R} \\
\mathrm{e} \\
\mathrm{g} \\
\mathrm{i} \\
\mathrm{o} \\
\mathrm{n}\end{array}$} & Yeojoo & $\begin{array}{r}174.3 \\
(100.0)\end{array}$ & 15.8 & $(17.2)$ & (13.1) & (43.9) & $(5.0)$ & $(20.1)$ & $(0.6)$ & - \\
\hline & $\begin{array}{c}\text { Ga- } \\
\text { pyeong }\end{array}$ & $\begin{array}{r}223.4 \\
(100.0)\end{array}$ & 22.3 & (33.8) & $(59.4)$ & - & $(6.8)$ & - & - & - \\
\hline & $\begin{array}{l}\text { Yang- } \\
\text { pyeng }\end{array}$ & $\begin{array}{r}93.7 \\
(100.0)\end{array}$ & 9.4 & (22.8) & $(14.2)$ & (37.4) & - & - & $(25.6)$ & - \\
\hline & $\begin{array}{l}\text { Dong- } \\
\text { duchon }\end{array}$ & $\begin{array}{r}146.1 \\
(100.0)\end{array}$ & 18.3 & $(63.0)$ & $(7.3)$ & - & $(29.8)$ & - & - & - \\
\hline & Ansung & $\begin{array}{r}74.7 \\
(100.0)\end{array}$ & 10.7 & (33.5) & (39.5) & (16.1) & $(5.4)$ & (2.3) & - & (3.3) \\
\hline
\end{tabular}

Note: 1) Numerical values of inside in the parentheses are percent of composition (\%).

2) A household that has 20 billion won gross incomes Yangpyeong country is excluded in the statistics.

3) ※ MAL: Managed arable land.

Source: The data was colleted from early july to early august, 2004 for 1 month by personal interview. 
among 32 households of the age of 30 s to $50 \mathrm{~s}$. The rest of 11 households engaged in a small-scale business, usual and temporary salaried labor. In addition, the residential differences presented that the households managed in agriculture and orchards, mushroom and garden tree cultivation were 2 and 5, respectively among 11 households in Yeojoo City. The households engaged in agriculture and orchards were 5 respectively in Gapyeong County and Yangpyeong County among 10 households. However, a small-scale business and temporary labor largely covered in Dongducheon City (Table 8).

In the viewpoint of the scale of managed arable land as a plan for agriculture and forestry management in the future, 18 households will increase the scale, 26 households will continue its current level, and 2 households will decrease the scale in which the reason for the increase of the scale was because of the plan for increasing a stable life and values of property, and for the maintenance and decrease of the scale were because of a low economic value and weakening and shortening of labor force. The enlargement of managed arable land presented a large number in the households managed in $1.0 \sim 1.5$ ha and the age of $40 \mathrm{~s}$ and $50 \mathrm{~s}$. In the case of the viewpoint of its residential aspect, the enlargement was largely required in Gapyeong County. In the forest management, 6 households wanted to enlarge the land due to the cultivation of garden trees and medicinal herbs. However, there were no households that they wanted to engage the forestation for a wood production purpose. In addition, the reason for maintaining the current level was because of low profits and lack of labor force (Table 9).

Table 8. The future household life plan.

(Unit: household)

\begin{tabular}{|c|c|c|c|c|c|c|c|c|c|}
\hline & Classification & Total & $\begin{array}{l}\text { Agricul- } \\
\text { ture } \\
\text { orchard }\end{array}$ & $\begin{array}{c}\text { Self } \\
\text { business }\end{array}$ & $\begin{array}{l}\text { Usual } \\
\text { salaried } \\
\text { labo }\end{array}$ & $\begin{array}{c}\text { Mush } \\
\text {-room } \\
\cdot \\
\text { Tree }\end{array}$ & $\begin{array}{l}\text { Temporary } \\
\text { salaried } \\
\text { labor }\end{array}$ & $\begin{array}{l}\text { Int- } \\
\text { rest }\end{array}$ & $\begin{array}{c}\text { No } \\
\text { Answer }\end{array}$ \\
\hline \multirow{6}{*}{$\begin{array}{l}※ \\
\stackrel{\mathrm{M}}{\mathrm{A}} \\
\mathrm{L}\end{array}$} & Total & 46 & 15 & 10 & 7 & 6 & 3 & 1 & 4 \\
\hline & No land & 11 & - & 3 & 2 & 1 & 2 & - & 3 \\
\hline & Under $0.5 \mathrm{ha}$ & 8 & 1 & 2 & 2 & 2 & - & 1 & - \\
\hline & $0.5 \sim 1.0 \mathrm{ha}$ & 16 & 8 & 3 & 2 & 1 & 1 & - & 1 \\
\hline & $1.0 \sim 1.5 \mathrm{ha}$ & 8 & 4 & 1 & 1 & 2 & - & - & - \\
\hline & Over $1.5 \mathrm{ha}$ & 3 & 2 & 1 & - & - & - & - & - \\
\hline \multirow{5}{*}{$\begin{array}{l}\mathrm{A} \\
\mathrm{g} \\
\mathrm{e}\end{array}$} & 30 's & 3 & 1 & - & 2 & - & - & - & - \\
\hline & 40 's & 10 & 3 & 3 & - & 2 & 1 & - & 1 \\
\hline & 50 's & 19 & 4 & 6 & 4 & 3 & 1 & 1 & - \\
\hline & 60's & 10 & 6 & - & 1 & 1 & - & - & 1 \\
\hline & Over 70's & 4 & 1 & 1 & - & - & & - & 2 \\
\hline \multirow{5}{*}{$\begin{array}{l}\mathrm{R} \\
\mathrm{e} \\
\mathrm{g} \\
\mathrm{i} \\
\mathrm{o} \\
\mathrm{n}\end{array}$} & Yeojoo & 11 & 2 & - & 3 & 5 & - & - & 1 \\
\hline & Ga-pyeong & 10 & 5 & 3 & 1 & 1 & - & - & - \\
\hline & Yangpyeng & 10 & 5 & 3 & 1 & - & - & 1 & - \\
\hline & Dongduchon & 8 & - & 4 & - & - & 3 & - & 1 \\
\hline & Ansung & 7 & 3 & - & 2 & - & - & - & 2 \\
\hline
\end{tabular}

Note: 1) ※MAL: Managed arable land.

Source: The data was colleted from early july to early august, 2004 for 1month by personal interview. 
Table 9. The plans for agriculture and forest.

(Unit: household)

\begin{tabular}{|c|c|c|c|c|c|c|c|c|c|}
\hline \multirow{2}{*}{\multicolumn{2}{|c|}{ Classification }} & \multirow[b]{2}{*}{ Total } & \multicolumn{2}{|c|}{$\begin{array}{l}\text { Plan of moving } \\
\text { mountain village }\end{array}$} & \multicolumn{3}{|c|}{$\begin{array}{l}\text { Managed arable land } \\
\text { scale }\end{array}$} & \multicolumn{2}{|c|}{$\begin{array}{l}\text { Forest management } \\
\text { scale }\end{array}$} \\
\hline & & & Stay & Move & Increase & $\begin{array}{c}\text { Main } \\
\text {-tain } \\
\text { current } \\
\text { level }\end{array}$ & $\begin{array}{l}\text { Decr- } \\
\text { ease }\end{array}$ & $\begin{array}{l}\text { Incre- } \\
\text { ase }\end{array}$ & $\begin{array}{c}\text { Main } \\
\text {-tain } \\
\text { current } \\
\text { level }\end{array}$ \\
\hline & Total & 46 & 43 & 3 & 18 & 26 & 2 & 6 & 40 \\
\hline$※$ & No land & 11 & 9 & 2 & 3 & 8 & - & 1 & 10 \\
\hline$\dddot{\mathrm{M}}$ & I Under 0.5 ha & 8 & 7 & 1 & 3 & 4 & 1 & 2 & 6 \\
\hline A & $0.5 \sim 1.0 \mathrm{ha}$ & 16 & 16 & - & 4 & 11 & 1 & - & 16 \\
\hline & $1.0 \sim 1.5 \mathrm{ha}$ & 8 & 8 & - & 6 & 2 & - & 3 & 5 \\
\hline & Over $1.5 \mathrm{ha}$ & 3 & 3 & - & 1 & 2 & - & - & 3 \\
\hline & 30 's & 3 & 3 & - & 1 & 1 & 1 & 1 & 2 \\
\hline A & 40 's & 10 & 10 & - & 5 & 5 & & 3 & 7 \\
\hline $\mathrm{g}$ & 50 's & 19 & 18 & 1 & 10 & 8 & 1 & 1 & 18 \\
\hline $\mathrm{e}$ & 60’s & 10 & 9 & 1 & 1 & 9 & - & - & 10 \\
\hline & Over 70's & 4 & 3 & 1 & 1 & 3 & - & - & $\because \quad-$ \\
\hline & Yeojoo city & 11 & 11 & - & 4 & 7 & - & 2 & 9 \\
\hline$R$ & $\begin{array}{c}\text { Ga-pyeong } \\
\text { country }\end{array}$ & 10 & 10 & - & 8 & 2 & - & 3 & 7 \\
\hline g & $\begin{array}{l}\text { Yangpyeng } \\
\text { country }\end{array}$ & 10 & 10 & - & 3 & 6 & 1 & - & 10 \\
\hline & $\begin{array}{l}\text { Dongduchon } \\
\text { City }\end{array}$ & 8 & - & - & 3 & 5 & - & 1 & 7 \\
\hline & Ansung city & 7 & 4 & 3 & - & 6 & 1 & - & 7 \\
\hline
\end{tabular}

Note: 1) ※MAL: Managed arable land.

Source: The data was colleted from early july to early august, 2004 for 1month by personal interview.

\section{Development projects of mountain settlements}

The development projects of mountain settlements for 5 investigated villages are as follows.

\section{Yeojoo City}

The waste incinerator installed in Yeojoo City was not used in recent years because of the resistance of the residents due to its smoke and lack of a budget for operating the incineration facility. It was not necessary to open a local specialty shop because the shop was not required in this area. In recent years, a local specialty shop has been operated as a retail shop by means of a lease contract for a person. Although the cold storage and dryer have been used in the present, there are some opinions that it cannot be widely used for all the residents due to the location of the facilities and its high operation cost. In addition, there was no common purse to operate and manage the facilities. In the case of the mortgage, there were 11 households that they applied by the mortgage of 1 household for a house building and enlargement and 6 households for the cultivation of Oak 
mushroom. However, 3 households considered canceling their mortgage due to the low income from the mushroom cultivation. The loan affected the household economy and was expected to change the mortgage to a support and enlarge the scale of mortgage. On the other hand, the residents who possessed their own land were easily supported in the Oak mushroom cultivation. However, the other residents were not easy to prepare a proper area to cultivate the Oak mushroom or canceled the support due to the cost of land in many cases. Therefore, there were a few indications that the development project of mountain settlements were aimed to a particular residents and a few residents who recognized the support and mortgage system due to lack of public information. However, the enlargement and pavement of a village road was highly evaluated by the residents. In addition, there were some opinions that the attraction of visitors, pavement of agricultural road, enlargement of the entrance will be required through the Oak mushroom cultivation, construction of a large scale chestnut tree complex, and creation of entertainment facilities. However, there was no discussion about a forestry industry and no interest about the issue.

\section{Gapyeong County}

In Gapyeong County, a common purse was created with as much as 65 million won in the present time by operating the visitors' lodgings using the visitors information centers and village halls in which the income of the visitors' lodgings in 2003 was 26 million won. There was some increase in the demands of fruit selling and private lodging due to the increase of visitors by improving the road applied by the development project of mountain settlements and the village environments installed by a sewage purification system. Moreover, there were many visitors in the forest and field around the village that will be designated a provincial park very soon and live in a garden house or private lodgings.

However, there were some indifferences and dissatisfactions for the development project of mountain settlements due to a lack of public information and preponderance of the supports. In addition, some residents were not exactly recognized about the project. On the other hand, used the mortage 10 households in which 2 households were used as a house construction and enlargement, 1 household was used as the Oak mushroom cultivation.

\section{Yangpyeong County}

In Yangpyeong County, the waste incinerator was also recognized as an inadequate facility in the state of agricultural and forest settlements. The village halls were leased to a person with a certain cost but will be used as a elderly house or private lodging after finishing the contract. The operational cost of the sewage purification system was supported by Yangpyeong County in which some facilities were neglected because of the high cost of repairs. The cold storage was also broken and neglected due to a lack of the well receiving of the residents for using the common funds. On the other hand, although 2.5 ha of the cultivation field of mountain ginseng and 400-pyung of the cultivation field of Codonopsis lanceolata as forage profit complex in 1996, there were no profits from the cultivation. On the other hand, there is a plan to sell the mountain ginseng as a type of potted ginseng in 2004 .

The mortgage that will be used to build a new house or enlargement was 3 households among 10 researched households. However, some households abandoned the mortgage due to its complicated process. There were some indications that the development 
Table 10. Development Projects of mountain settlements in the study regions.

(Unit: hundred won)

\begin{tabular}{|c|c|c|c|c|c|c|c|c|}
\hline \multicolumn{3}{|c|}{ Classification } & Total & Yeojoo & $\begin{array}{c}\text { Ga- } \\
\text { pyeong }\end{array}$ & $\begin{array}{l}\text { Yang- } \\
\text { pyeng }\end{array}$ & $\begin{array}{l}\text { Dongdu- } \\
\text { chon }\end{array}$ & Ansung \\
\hline & & Total & 7,206 & 1,424 & 1,179 & 1,756 & 1,792 & 1,055 \\
\hline \multirow{13}{*}{\multicolumn{2}{|c|}{$\begin{array}{l}\text { Changing the } \\
\text { supplement } \\
\text { environment }\end{array}$}} & Sub-total & 2,491 & 291 & 244 & 1,268 & 619 & 69 \\
\hline & & Incinerator & 131 & 28 & - & 72 & - & 31 \\
\hline & & Village hall & 433 & 103 & - & 330 & - & - \\
\hline & & Temporary lavatory & 21 & - & - & - & - & 21 \\
\hline & & Maintenance path up Mt. & 3 & 3 & - & - & - & - \\
\hline & & $\begin{array}{l}\text { Sewage purifi- } \\
\text { cation system }\end{array}$ & 372 & - & 25 & 347 & - & - \\
\hline & & Water playground & 43 & - & - & 43 & - & - \\
\hline & & Tacilites of forest culture & 3 & - & 3 & - & - & - \\
\hline & & aintenance of village road & 274 & 129 & 74 & 71 & - & - \\
\hline & & $\begin{array}{l}\text { Facility of village broad- } \\
\text { casting }\end{array}$ & 48 & - & 48 & - & - & - \\
\hline & & Established of farm road & 125 & - & - & 125 & - & - \\
\hline & & $\begin{array}{l}\text { Water service and } \\
\text { sewer system }\end{array}$ & 619 & - & - & - & 619 & - \\
\hline & & Other & 419 & 28 & 94 & 280 & - & 17 \\
\hline \multirow{8}{*}{\multicolumn{2}{|c|}{$\begin{array}{l}\text { Changing the } \\
\text { supplement } \\
\text { environment }\end{array}$}} & Sub-total & $\begin{array}{r}2,907 \\
(40.3)\end{array}$ & $\begin{array}{r}725 \\
(50.9)\end{array}$ & $\begin{array}{r}775 \\
(65.7)\end{array}$ & $\begin{array}{r}255 \\
(14.5)\end{array}$ & $\begin{array}{r}250 \\
(14.0)\end{array}$ & $\begin{array}{r}902 \\
(85.5)\end{array}$ \\
\hline & & Cold storage & 204 & 54 & - & - & 82 & 68 \\
\hline & & Local specialty shop & 627 & 103 & 104 & 181 & 99 & 140 \\
\hline & & $\begin{array}{l}\text { Mushroom cultivation } \\
\text { complex }\end{array}$ & 1,042 & 444 & - & - & - & 598 \\
\hline & & Dryer & 6 & 6 & - & - & - & - \\
\hline & & Forage profits complex & 74 & - & - & 74 & - & - \\
\hline & & $\begin{array}{l}\text { Visitors information } \\
\text { center }\end{array}$ & 240 & - & 240 & - & - & - \\
\hline & & Other playground & 714 & 118 & 431 & - & 69 & 96 \\
\hline \multirow{6}{*}{$\begin{array}{l}\text { Fina- } \\
\text { ncing }\end{array}$} & \multirow[t]{2}{*}{$\begin{array}{l}\text { House } \\
\text { inpro- } \\
\text { vement }\end{array}$} & $\begin{array}{l}\text { Construction } \\
\text { and } \\
\text { enlargement }\end{array}$ & $\begin{array}{r}1,140 \\
(15.8)\end{array}$ & $\begin{array}{r}88 \\
(6.2)\end{array}$ & $\begin{array}{r}160 \\
(13.6)\end{array}$ & $\begin{array}{r}140 \\
(8.0)\end{array}$ & $\begin{array}{r}752 \\
(42.0)\end{array}$ & - \\
\hline & & Sub-total & $\begin{array}{r}668 \\
(9.3)\end{array}$ & $\begin{array}{r}320 \\
(22.5)\end{array}$ & - & $\begin{array}{r}93 \\
(5.3)\end{array}$ & $\begin{array}{r}171 \\
(9.5)\end{array}$ & $\begin{array}{r}84 \\
(8.0)\end{array}$ \\
\hline & \multirow{4}{*}{$\begin{array}{l}\text { Profit } \\
\text { source } \\
\text { project }\end{array}$} & $\begin{array}{l}\text { Cultivation } \\
\text { mushroom }\end{array}$ & 418 & 320 & - & 14 & - & 84 \\
\hline & & $\begin{array}{l}\text { Weekend } \\
\text { form }\end{array}$ & 13 & - & - & 13 & - & - \\
\hline & & Cultivation herbs & 92 & - & - & 37 & 55 & - \\
\hline & & Other & 142 & - & - & 29 & 116 & - \\
\hline \multicolumn{3}{|c|}{ Project of other government branches } & 1,599 & - & - & - & 1,241 & 358 \\
\hline \multicolumn{3}{|c|}{ Subside for forest works } & 1,700 & - & - & - & 161 & 1,539 \\
\hline
\end{tabular}

Note: 1) Numerical values of inside in the parentheses are percent of composition (\%).

2) Projects of other government branches are excluded in the total. 
project of mountain settlements was performed by the authorities centered way in spite of regarding the public opinions during the project was processed. In addition, it was pointed that the supports of funds to increase a managed arable land and active public information of the village using the internet, and supports of the costs for the facilities maintenance were required to develop this mountain settlement. On the other hand, the common fund was reserved by 20 million won in the present in which 5 million won was reserved every month through the festival of Acer mono sap. In addition, there were many opinions that the demands of private lodgings increased due to the increase in visitors, and the village environments were also improved by the development project of mountain settlements.

Dongducheon City

The cold storage has been used as storage of vegetables because of low demands of use and its cost was supplied by the common funds. The specialty shop was also leased by free for a different usage for the low use of it. There were some opinions that the project helped an increase of household income due to an increase in visitors by purifying the river introduced by a sewage purification system, arranging the road and streetlights. In the case of the mortgage that was done for 5 households among 8 households to build a new house of enlargement, however, there were some indications that the scale of mortgage was small, short term of refunds, high rate of interest. In addition, some households wanted to use more actively the surrounding public areas of village than the facilities that were not much needed in the village.

Ansung City

The waste incinerator installed in Ansung City has not been used in recent years because of the long distance from its installation and lack of a budget for operating the incineration facility. The cold storage was also used as a different usage in which it has been used as storage of the Oak mushrooms. Users themselves paid the cost for operation. The specialty shop was not used by 2004 but was used as a restaurant by receiving a reservation of visitors. In the case of the Oak cultivation, 2 households has been cultivated among 7 households. However, they will reduce or stop the cultivation due to a lack of market and low price even though they get a few incomes. It was investigated that the investment of facilities and projects were not properly processed due to lack of the examination of the regional characteristics in the development project of mountain settlements. In addition, the age of people their over 60 s and 70 s presented an indifference manner for the development project of mountain settlements (Table 10).

\section{CONCLUSIONS}

1. The age composition of the researched 46 households was $65 \%$ of the age over 50 s. The managed arable land was 0.6 ha as a small scale. The sale of the production base like a rice and ordinary field was higher than the purchase by two times. In the case of a forest and field, the scale of managed arable land and forest has been decreased because the sale was higher than the purchase.

2. The average gross income per household was 15.5 million won that was a low level and not reached to $60 \%$ of the country's agricultural household income. In addition, the gross agricultural household income for the whole gross income of household was also 
a low level of $29 \%$.

3. For the future household life, the configuration presented 15 households of agriculture and orchards, and 6 households of mushroom and garden trees cultivation among 46 households in which 6 households expected to increase the scale of management because of the cultivation of garden trees and medicinal herbs and values of the property. However, there was no household that they wanted to engage the forestation for a wood production purpose.

4. There were a lot of residents who presented indifference for the project due to a lack of public information and discussions in many areas even though the village environments were improved by some performances in a certain area, such as the arrangement of a road, installation of a sewage purification system, increase of private lodgings due to an increase in visitors, creation of a common fund. It was investigated that the investment of facilities and projects were not properly processed due to lack of the examination of the regional characteristics in the development project of mountain settlements. Moreover, a management method for local forest was almost not discussed.

From the investigations mentioned above, the opened issues are as follows.

1. The outflows of labor force, aging, and lack of a successor will act as a lowering factor of the depression of the development project of mountain settlements and activities of mountain settlements. Therefore, it is necessary to secure the young labor forces of the younger and middle aged generation through the stabilization of profits base in order to continue the development of mountain settlements.

2. The local residents decreased far from increasing due to aging, lack of labor forces, small-scale arable land, low grade of forest management, and not various incomes in spite of the improvement of a settlement base by introducing a forest development project. Therefore, it is necessary to secure and support various projects to increase the actual household income including the facilities for the base of settlement.

3. In order to process an effective development project of mountain settlements, it is required that investment will be performed by considering the characteristics of local area. In addition, the active participation of the local residents through a good enough discussion and reflection of residents' opinion are more important than anything else.

4. A continuous management will be required to operate the facilities installed in the development project of mountain settlements. In addition, it is necessary to support a cultivation method and additional supports like the distributions and sales of the forest products and to extend the sales and interchange with urban residents through public information like Internet in order to make increasing an activation of mountain settlements.

5. The objective of the development project of mountain settlements is ultimately aimed to the balanced development of country, wood production, and public profits through a forest management. Therefore, it is necessary to enhance the more active forest management and managing method for the development project of mountain settlements in the future.

6 . Finally, it shows that the function of mountain settlements increases not only an economical production but also various public functions of forest based on the changes of 
people's values for the nature and forest. Therefore, it is necessary to guarantee a more powerful promotion policy for the health development of mountain settlements.

\section{REFERENCES}

Shon, C. H and W. W Chang. 2002 A Status and Improvement Direction of Case Areas. Korean Forest Economics Society, 10(2): 106-116

Kim, E. K. 2002 Changes and Direction of Mountain Village Development in Korea. Korean Forest Economics Society, 10(2): 95-105

Gyeonggi province 2003a A report of nationwide basic census of forest settlement (Gyeonggi province): $1-401$

Gyeonggi province 2003b The plan of development project for mountain settlement of 2003: 1-27

Gyeonggi province 2003c The propulsion status of development project for mountain settlement of Gyeonggi-province

Gyeonggi province 2004 Results of development project for mountain settlement against its plan

Korea Forest Service 2003a A guidebook for basic census of forest settlements: 1-59

Korea Forest Service 2003b An annual report about forest and forestry: 283-306

Korea Forest Service 2003c Propulsion plans of main business of 2004: 90-91

Kwak, K. H and S. B. Kim 2002 Management Status and Development Direction of Case Areas in Mountain Village Package Development. Korean Forest Economics Society, 10(2): 106-116 